\title{
Het MAB voor 50 jaar
}

april 1937

Accountant G. P. J. Hogeweg, lid van de redactie van het MAB, bespreekt enkele facetten van het Deutsches Fachkongress für das Prüfungs- und Treuhandwesen, dat in het najaar van 1936 in Weimar is gehouden. Namens de nationaal-socialistische regering werden toespraken gehouden, welke duidelijk lieten uitkomen, dat niet in de eerste plaats het vak van Wirtschaftsprüfer, ook niet de onderneming welke gecontroleerd wordt, door de Wirtschaftsprüfer en -Treuhänder gediend moest worden, maar de Staat en de Volksgemeenschap: geen particulier belang mag worden gediend, als dat niet volkomen samen gaat met dat van de Staat en de Volksgemeenschap!

Reichsminister Frank zei o.a.: 'Nicht mehr Interessenvertreter zu sein, sondern Vollstrecker deutschen Rechts in einer deutschen Wirtschaft ist Ihr Aufgabe, meine Herren'. Voorts: 'Als nationalsozialistische Rechtswahrer ist es für Sie selbstverständlich dass Sie Ihren Beruf, das Prüfungsund Treuhandwesen, voll und ganz mit den in den Dienst dieser grossen Aufgabe des nationalsozialistischen Vierjahresplanes der Wirtschaft stellen'.

Het valt Hogeweg op, dat de Treuhand-en Wirtschaftspruferberoepen niet wat scherper uiteengehouden worden, omdat z.i. er toch veel in zit, dat niet geheel te zamen hoort. Blijkbaar zoekt men z.i. in Duitsland meer naar wat verenigt dan naar wat verdeelt.

Een der andere sprekers op het congres meende dat Wirtschaftsprüfer en Treuhänder 'Bännerträger des Sozialismus in der Wirtschaft' moeten zijn.

In een uitvoerig artikel merkt accountant A. M. Groot - ik meen dat hij destijds aan de Nederlandse Spoorwegen verbonden was - een en ander op betreffende de bedrijfseconomische zijde van het verkeersvraagstuk. De opkomst van het wegverkeer en de verbetering van de motorisering van de binnenvaart brengen een enorme omwenteling in de organisatie van het verkeerswezen. Met de vroeger uitgebalanceerde concurrentie tussen spoorweg en waterweg is het gedaan. Spoor en verkeer te water brachten de goederen alleen tot aan het station of de aanlegsteiger bij plaatsen langs de 
waterweg. Vandaar moest men maar zien hoe de vracht op de uiteindelijke plaats van bestemming kwam. Het zich verder ontwikkelende wegverkeer is in staat rechtstreeks bij de geadresseerde te komen en kan opereren in streken waar geen waterwegen zijn. De verbetering van de techniek had o.a. grotere snelheden tot gevolg, waardoor een gelijk vervoersvolume toch een groter aantal ton-kilometers ging opleveren.

Dit, te zamen met de gevolgen van de economische crisis in de jaren dertig, leverde een overcapaciteit van aanbod op. Hierbij komt, dat de vaste lasten per eenheid relatief zeer hoog zijn, zodat een overcapaciteit niet automatisch tot afbouw van het aanbod leidde. Gaat een fabriek failliet, dan vervalt veelal de desbetreffende capaciteit. Bij vervoersbedrijven - meestal kleine bedrijven - wordt bij faillissement de vervoerseenheid gemakkelijk overgenomen door een ander, die er vanwege de lage overname-prijs nog wel brood in ziet.

De auteur verwijt de wetenschappelijke bedrijfseconomie zich tot dusver weinig met de problematiek van het verkeer te hebben beziggehouden. Groot noemt o.a. de vraag of het wegverkeer voldoende belastingopbrengst oplevert om de economische kosten voor de instandhouding en vervanging van het wegennet te dekken. Er zijn volgens hem wel talrijke publikaties, doch de uitkomsten van de daarin vervatte becijferingen wijzen z.i. zulke fantastische verschillen uit, dat ze als onbruikbaar en onbetrouwbaar verworpen moeten worden. De opvatting van velen, dat het verkeerswezen voor de overheid een uiterst winstgevende zaak zou zijn - zodat men uit de opbrengst van de benzinebelasting zelfs de tekorten van de spoorwegen zou kunnen dekken - verwijst Groot naar het land der fabelen. Van nog meer belang is nog het kostenvraagstuk en het hiermede samenhangende probleem der tarieven. Ook hier staat men volgens Groot nog aan het begin van een bedrijfseconomisch onderzoek. Het reeds eerder genoemde vraagstuk van de overcapaciteit vraagt eveneens een betere aanpak.

Groot hoopt dat vooral de jongere bedrijfseconomen hun afzijdigheid in deze materie zullen prijsgeven.

Mr. Th. W. Branbergen komt terug op het naschrift van collega Van Essen terzake van het verschoningsrecht van de accountant (zie het historisch verslag in МАВ dec. 1986). Aan de geestelijke, de medicus en de advocaat wordt het verschoningsrecht toegekend, niet uit hoofde van de persoon aan wie zij hulp verlenen, maar krachtens de aard van de hulp, die zij verlenen. (Van Essen had zich nl. afgevraagd of het dan alleen zondaren of zieken of boosdoeners - en niet anderen - zijn, die behoefte hebben aan hulp, welke hun dan alleen goed kan worden verstrekt als zij zonder terughouding kunnen opbiechten). De door Branbergen bedoelde hulp is van geestelijke, lichamelijke of rechtsgeleerde aard, niet van materiële aard. Vandaar de grens tussen de drie reeds genoemde beroepen enerzijds en die van accountant, bankier en makelaar enz. anderzijds. Die 'hogere' waarde boven het materiële rechtvaardigt z.i. het verschoningsrecht als een algemeen belang, dat prevaleert boven het belang, dat 'recht gesproken worde met zoo groot mogelijke waarborg tot de waarheid te kunnen doordringen'.

Branbergen houdt dus vol, dat de accountant z.i. het verschoningsrecht niet 
toekomt. Wanneer dat tot gevolg zou hebben dat iemand, die liever accountantshulp ontbeert dan de kans te lopen dat zijn accountant genoodzaakt kan worden als getuige gegevens mede te delen, 'dan brengt diegene niet zijn ziel, zijn leven, de rechtvaardigheid, maar slechts zijn administratie, zijn zaken, zijn vermogen in gevaar'.

Van Essen blijft van mening, dat het onbeschroomd kunnen raadplegen van de accountant een algemeen belang is. En al dient hij in de eerste plaats met zijn adviezen het persoonlijk belang van zijn cliënt, hij dient ook een wijder, een algemeen belang, nl. de Welvaart (zoals volgens v.E. een medicus in de eerste plaats zijn patiënt hulp van materiële - = lichamelijke - aard verleent en hierdoor het belangrijke immateriële belang van de Volksgezondheid dient).

Het nieuwe artikel van Branbergen, met naschrift van Van Essen, brengt op een aantal ondergeschikte punten wel wederzijdse opheldering, doch op de essentiële punten blijven de meningen verdeeld.

Uit het recente artikel van Mr. A. F. M. Dorresteijn - zie MAB jan. 1987 blijkt, dat het vraagstuk van het verschoningsrecht nog niets van zijn actualiteit verloren heeft.

In het historisch verslag in het februari-nummer van dit jaar beloofde ik terug te komen op het commentaar, dat collega Haarbosch had geschreven bij de nieuwe regeling van toezicht in Frankrijk op jaarrekeningen van vennootschappen. In het april-nummer van 1937 hebben de collegae J. C. A. van der Spil en M. M. Deen Jr - los van elkaar - de redactie er op attent gemaakt, dat het Franse begrip 'commissaire' allerminst het begrip 'commissaris ener vennootschap' zoals wij dit in ons land kennen, dekt. Volgens beide collegae bestaan dergelijke commissarissen in Frankrijk niet (of het zou zijn, dat men hen met de titel administrateur zou moeten aanduiden). Met commissaire bedoelt men aldaar degene die uitsluitend belast wordt met de controle van de jaarrekening, derhalve tevens de boekhouding omvattend. Zij hebben dus niet de taak van toezicht op het bestuur ener vennootschap, zoals dat bij onze commissaris het geval is.

Hiermede komt de uiteenzetting van Haarbosch inzake de ongewenste combinatie van functies op losse schroeven te staan.

De redactie van het MAB verontschuldigt zich en voert als oorzaak van de vergissing aan, dat het bureau dat met de vertaling van het Franse decreet was belast 'een leelijke fout heeft gemaakt, die de beteekenis van de bepalingen belangrijk heeft gewijzigd'.

In een resolutie van 19 januari 1937 heeft de minister van Financiën de aandacht van de ambtenaren er op gevestigd, dat z.i. de nieuwe theorieën (bedoeld wordt o.a. de leer van de vervangingswaarde) 'nog niet een zoodanige toepassing vinden, dat men een koopmansgebruik aanwezig kan achten'. Redacteur Mr. Dr. E. Tekenbroek is van mening dat met deze resolutie het laatste woord nog niet is gesproken. Hij verwacht, dat men op de lange duur er niet aan zal ontkomen dit begrip in meerdere mate te oriënteren naar de resultaten waartoe de bedrijfseconomie is gekomen. 